\title{
Evaluation of CYP2D6 Polymorphic Types and Their Effect on Tamoxifen Efficacy Among Turkish Tamoxifen Users with Breast Cancer
}

\author{
Meral GUNALDI ${ }^{1}$, Melek ERKISI ${ }^{2}$, Cigdem AFSAR ${ }^{2}$, Vehbi ERCOLAK ${ }^{3}$, Berna DUMAN $^{4}$, \\ Semra PAYDAS ${ }^{2}$, Ismail KARA ${ }^{2}$, Berksoy SAHIN $^{2}$, Abdullah TULI ${ }^{5}$, Ata SECILMIS ${ }^{6}$ \\ ${ }^{1}$ Bakirkoy Dr. Sadi Konuk Research and Training Hospital, Department of Medical Oncology, Istanbul \\ ${ }^{2}$ Çukurova University Faculty of Medicine, Department of Medical Oncology, Adana \\ ${ }^{3}$ Harran University Faculty of Medicine, Department of Medical Oncology, Sanliurfa \\ ${ }^{4}$ Adana Numune Research and Training Hospital, Department of Medical Oncology, Adana \\ ${ }^{5}$ Cukurova University Faculty of Medicine, Department of Biochemistry, Adana \\ ${ }^{6}$ Cukurova University Faculty of Medicine, Department of Pharmacology, Adana, TURKEY
}

\begin{abstract}
In this study we investigated the role of the polymorphic types of CYP2D6 in the Turkish population for therapeutic efficacy among patients with early stage breast cancer who treated with tamoxifen. CYP2D6 plays an important role in tamoxifen metabolism. CYP2D6 genotypes were determined of 115 patients treated with adjuvant tamoxifen using the AmpliChip CYP450 test. Genotypes were classified by metabolizer groups and evaluated by the diagnostic and clinical characteristics of the patients and the recurrences of the disease. To create an intergroup comparison of the categorical measurements, the Chi-Square test was used. The most common CYP2D6 gene polymorphism was ${ }^{*} 1 /{ }^{*} 2$ with a percentage of $19.9 \%(n=19)$. In the Turkish population, among patients with early stage breast cancer, the normal metabolizer group was the largest with a percentage of $77.1 \%(n=74)$. The percentage rates were determined to be $11.5 \%$ $(n=11)$ for intermediate metabolizers, $5.2 \%(n=5)$ for ultrarapid metabolizers and $2.1 \%(n=2)$ for poor metabolizers. In patients with early stage breast cancer treated with adjuvant tamoxifen. no significant correlation was detected between CYP2D6 types and recurrence and metastasis rates. This study was the first study to determine CYP2D6 genotypes and characteristics of Turkish patients with early stage breast cancer. Although no correlation was demonstrated between CYP2D6 genotype polymorphism and disease recurrence in the earlier period, long-term follow-ups seem to be warranted.
\end{abstract}

Keywords: Breast cancer, CYP2D6, Tamoxifen

ÖZET

Tamoksifen Kullanan Meme Kanserli Türk Hastalarda CYP2D6 Gen Polimorfizm Tiplerinin Tamoksifen Etkinliğine Etkinliklerinin Değerlendirilmesi

Biz bu çalışmada, erken evre meme kanseri tedavisinde tamoksifen kullanan Türk hastalarda CYP2D6 gen polimorfizmleri ile tedavi etkinliği arasındaki ilişkiyi araştırdık. Adjuvant tamoksifen kullanan 115 hastanın CYP2D6 genotipleri AmpliChip CYP450 test kullanılarak belirlendi. Metaboze edici gruplar genotiplere gore sınıflandırılarak tanı, klinik ve hastalığın tekrarı ile değerlendirildi. Sınıllandırılan ölçümlerin karşılaştırımasında Ki-kare testi kullanıldı. En sık CYP2D6 gen polimorfizmi 19.9\% ( $n=19)$ ile *1/*2 idi. Erken evre meme kanserli Türk hastalarda 77.1\% ( $n=74)$ normal metabolize edici grup en büyük grubu oluşturdu. Orta metabolize edici grup 11.5\% ( $n=11), 5.2 \%(n=5)$ hızlı metabolize edici grup, $2.1 \%(n=2)$ yavaş metabolize edici grup olarak saptandı. Tamoksifenle tedavi edilen erken evre meme kanserli hastalarda CYP2D6 gen polimorfizmleri ile hastalık tekrarı ve metastazı arasında anlamlı bir ilişki saptanmadı. Erken evre meme kanserli Türk hastalarda CYP2D6 genotipleri ve özelliklerini saptayan illk çalışmadır. CYP2D6 genotip polimorfizmleri ve hastalık tekrarı arasında erken dönemde bir ilişki saptanmasa da uzun dönem takibe intiyaç olduğu görünmektedir.

Anahtar Kelimeler: Meme kanseri, CYP2D6, Tamoksifen 


\section{INTRODUCTION}

Tamoxifen is a selective estrogen receptor modulator. It is efficient in the prevention of recurrence in patients with estrogen receptor positive $(E R+)$ breast cancer and in the protection of women with a high risk of developing breast cancer. However, in some patients, tamoxifen did not have the expected outcome. Tamoxifen is a prodrug that is converted into its active metabolite 4-hydroxy tamoxifen and endoxifen by the cytochrome p450 (CYP2D6) enzyme system in the liver. ${ }^{1,2}$ To date, more than 100 variants of this enzyme have been described. These variants were classified into four groups by their rate of metabolizing the tamoxifen: normal metabolizer (NM), intermediate metabolizer (IM), ultrarapid metabolizer (UM) and poor metabolizer (PM). ${ }^{3}$ The distribution of these groups varies between regions and ethnicities. Until now, no study has been performed to show the distribution of these groups in the Turkish population.

In this study, we investigated the distribution of the metabolizer groups by CYP2D6 genotypes and the role of these groups in the efficacy of the drug in Turkish patients with ER+ early stage breast cancer treated with adjuvant tamoxifen.

\section{PATIENTS AND METHODS}

This study included 115 patients with early stage breast cancer who were were admitted to an outpatient clinic and were treated with $20 \mathrm{mg}$ of adjuvant tamoxifen. They were chosen from a group of 1068 patients diagnosed with breast cancer presented to department of medical oncology between 2007 and 2012.

\section{Sample Collection and Analysis}

A peripheral venous blood sample was obtained from each patient in an EDTA tube that was stored at -800C. CYP2D6 genotyping was performed by operators blinded to the clinical data. Genomic DNA was extracted utilizing a QIAamp DNA Blood Midi Kit (Qiagen, Valencia, CA) and the eluates reached 10 $\mathrm{ng} / \mu \mathrm{L}$ using Nanodrop. To determine the CYP2D6 genotype, patient DNA samples were analyzed using the $\mathrm{xTAG}^{\mathrm{TM}}$ CYP2D6 v2 Kit (Austin, Texas).

We used a polymerase chain reaction (PCR) 9700 thermal cycler (PE Applied Biosystems) with the following conditions: initial denaturation at $98^{\circ} \mathrm{C}$ for 3 min, followed by 35 cycles of $95^{\circ} \mathrm{C}$ for $60 \mathrm{sec}, 66^{\circ} \mathrm{C}$ for $30 \mathrm{sec}, 72^{\circ} \mathrm{C}$ for $2 \mathrm{~min} 30 \mathrm{sec}$, and a final elongation step at $72^{\circ} \mathrm{C}$ for $5 \mathrm{~min}$. PCR products, amplicons, were hybridized put onto the microarray and stained with a streptavidin-phycoerythrin conjugate. Fluorescence associated with hybridization to specific probe features was detected by a laser-illuminated, confocal scanner and the radiation in these wells was read and reported using a Luminex ${ }^{\circledR} 200$ xMAP device.

Data analysis software interpreted the hybridization pattern of probes that were specifically complementary to either wild type or mutant sequences for each polymorphic site. The assay also detected the presence of gene duplications and gene deletions. A total of alleles, including CYP2D6 *1, *2, *3, *4, *5 (deletion), *6, *7, *8, *9,*10,*11,*15,*17,*41, were evaluated (http://www.imm.ki.se/CYPalleles/ cyp2d6.htm). Allele types were divided into four subgroups by their activity: CYP2D $6 * 1, * 2, * 35$, functional or wild type alleles; CYP2D6 $* 9, * 10$, $* 17, * 41$, partially active alleles; CYP2D $6 * 3, * 4, * 5$, $* 6, * 7, * 8$, inactive alleles; CYP2D6 *1xN, *2xN, $* 35 \times \mathrm{N}, * 4, * 10, * 41$, duplicated genes. As predicted CYP2D6 phenotype was classified into four categories as it originated from CYP2D6 allele genotypes. While normal metabolizers contain two active CYP2D6 alleles or one active and one partially active allele, intermediate metabolizers contain one active and one inactive allele or one inactive or one partially active CYP2D6 allele. Poor metabolizers don't contain any active CYP2D6 alleles. Ultrarapid metabolizers contain 3 or more active CYP2D6 alleles due to the duplication of one active allele.

\section{Statistical Analysis}

Patient characteristics were prepared according to case characteristics in the form of a chart. For the statistical analysis, SPSS 19.0 software was used SPSS (Inc., Chicago, USA). Categorical measurements were summarized as number and percentage while numeric measurements were summarized as mean and standard deviation. To complete an intergroup comparison of the categorical measurements, the Chi-Square test was used. Those with $\mathrm{P}<0.05$ were considered to be significant. The correlation between disease metastasis and CYP2D6 was analyzed using the Kaplan-Meier method. 


\begin{tabular}{|c|c|c|c|}
\hline Characteristics of patients & & $\begin{array}{c}\text { Total }(n=96) \\
\text { Number of patients }\end{array}$ & $\%$ \\
\hline \multirow[t]{3}{*}{ Age } & Min & 32 & \\
\hline & Median & 45 & \\
\hline & Max & 62 & \\
\hline \multirow[t]{2}{*}{ Menopausal status } & Premenopausal & 89 & 92.71 \\
\hline & Postmenopausal & 7 & 7.29 \\
\hline \multirow[t]{3}{*}{ Histology } & Ductal & 78 & 81 \\
\hline & Lobular & 11 & 11.45 \\
\hline & Other & 2 & 2 \\
\hline \multirow[t]{3}{*}{ Tumor size (cm) } & $\mathrm{Tis} / \mathrm{T} 1$ & 25 & 26.86 \\
\hline & $\mathrm{T} 2$ & 51 & 52.81 \\
\hline & $\mathrm{T} 3 / \mathrm{T} 4$ & 20 & 20.22 \\
\hline \multirow[t]{3}{*}{ Nodal status } & No & 42 & 43.48 \\
\hline & N1 & 27 & 28.26 \\
\hline & N2 & 27 & 28.26 \\
\hline \multirow[t]{3}{*}{ Grade } & I & 7 & 7.3 \\
\hline & $\|$ & 60 & 62.5 \\
\hline & III & 21 & 21.9 \\
\hline \multirow[t]{4}{*}{ Estrogen receptor status } & $<50$ & 25 & 26 \\
\hline & $50-80$ & 27 & 28 \\
\hline & $81-90$ & 23 & 24 \\
\hline & $>90$ & 21 & 21 \\
\hline \multirow[t]{4}{*}{ Progesterone receptor status } & $<10$ & 24 & 25.0 \\
\hline & $10-50$ & 27 & 28.1 \\
\hline & $51-80$ & 27 & 28.1 \\
\hline & $>80$ & 18 & 18.8 \\
\hline \multirow[t]{2}{*}{ HER-2 } & Negative & 27 & 28.1 \\
\hline & Positive & 67 & 69.8 \\
\hline \multirow[t]{3}{*}{ Stage } & I & 17 & 17.7 \\
\hline & $\|$ & 43 & 43.8 \\
\hline & III & 35 & 36.9 \\
\hline \multirow[t]{2}{*}{ Metastasis/Recurrence } & Yes & 5 & 5.2 \\
\hline & No & 90 & 93.8 \\
\hline \multirow[t]{3}{*}{ Follow-up, months } & Minimum & 6 & \\
\hline & Median & 32 & \\
\hline & Maximum & 71 & \\
\hline
\end{tabular}

\section{RESULTS}

A total of 115 patients with breast cancer treated with adjuvant tamoxifen were enrolled in the study. DNA isolation could be performed in 92 patients and relevant data were collected. The mean age of the patients (mean age $\pm \mathrm{SD}$ ) was $44,81 \pm 6.44$ years. The follow-up duration of the patients was 6-71 months (mean $=32$ months) (Table 1).

Of the patients, $92.71 \%(\mathrm{n}=89)$ were premenopausal and $7.29 \%(\mathrm{n}=7)$ were post-menopausal. Of the patients, $85.4 \%(\mathrm{n}=82)$ underwent a modified radical mastectomy, 9.4\% ( $\mathrm{n}=9)$ underwent breast-sparing surgery and $3.1 \%(n=3)$ underwent excisional surgery. Of the pathologies, $81 \%(n=78)$ were inva- sive ductal carcinoma, $11.45 \%(\mathrm{n}=11)$ were invasive lobular carcinoma and $2 \%(\mathrm{n}=2)$ were "others". Of the cases, $7.3 \%(n=7)$ were Grade I, 62.5\% $(n=60)$ were Grade II and $21.9 \%(n=21)$ were Grade 3. While $69.8 \%(n=67)$ of the patients were $\operatorname{HER}(+), 28.1 \%$ $(\mathrm{n}=27)$ were HER2 (-). Of those observed, $17.7 \%$ $(n=17)$ had Stage I breast cancer, $43.8 \%(n=43)$ had Stage II and $36.9 \%(n=35)$ had Stage III. During the follow-up, 93.8\% ( $n=90)$ of the patients did not develop metastasis, whereas $5.2 \%(n=5)$ were observed to have developed metastasis (Table 1).

The most common CYP2D6 gene polymorphism was $* 1 / * 2$ with a percentage of $19.9 \%(n=19)$. Thereafter, the incidences of $* 1 / * 41, * 1 / * 1, * 1 / * 4, * 1 / * 10$ 


\begin{tabular}{|c|c|c|}
\hline Allele Genotype & $\mathbf{n}$ & $\%$ \\
\hline $1^{*} 1^{*}$ & 11 & 11.95 \\
\hline $1 * 10^{*}$ & 8 & 8.69 \\
\hline $1^{\star} 17^{*}$ & 1 & 1.08 \\
\hline $1^{\star} 2^{\star}$ & 19 & 20.65 \\
\hline $1^{*} 3^{*}$ & 1 & 1.08 \\
\hline $1^{\star} 4^{\star}$ & 9 & 9.78 \\
\hline $1^{\star} 41^{*}$ & 14 & 15.21 \\
\hline $1^{\star} 5^{\star}$ & 1 & 1.08 \\
\hline $1^{\star} 7^{\star}$ & 2 & 2.17 \\
\hline $10^{*} 10^{*}$ & 1 & 1.08 \\
\hline $10^{\star} 41^{\star}$ & 1 & 1.08 \\
\hline $2^{*} 1^{*}$ & 1 & 1.08 \\
\hline $2^{\star} 2^{\star}$ & 3 & 3.26 \\
\hline $2^{\star} 4^{*}$ & 6 & 6.52 \\
\hline $2^{\star} 41^{*}$ & 3 & 3.26 \\
\hline $2^{*} 6^{\star}$ & 1 & 1.08 \\
\hline $3^{\star} 4^{\star}$ & 1 & 1.08 \\
\hline $3^{\star} 7^{\star}$ & 1 & 1.08 \\
\hline $4^{\star} 41^{\star}$ & 3 & 3.26 \\
\hline $41^{*} 41^{*}$ & 3 & 3.26 \\
\hline $5^{\star} 41$ & 1 & 1.08 \\
\hline $6^{*} 6^{*}$ & 1 & 1.08 \\
\hline Total & 92 & 100.0 \\
\hline
\end{tabular}

were found to be $14.6 \%(n=14), 11.5 \%(n=11), 9.3 \%$ and $8.3 \%$, respectively. The most commonly seen allele was $* 1$ with an incidence of $81.3 \%(n=78)$ (Table 2).

CYP2D6 gene polymorphisms were classified by metabolizer groups: $77.1 \%(\mathrm{n}=74) \mathrm{NM}, 11.5 \%(\mathrm{n}=11)$ IM, 5.2\% ( $n=5)$ UM and 2.1\% (n=2) PM (Table 3).

No significant difference was found between CYP2D6 genotypes and tumor size or lymph node involvement of the patients $(\mathrm{p}=0.3, \mathrm{p}=0.4)$.

ER, PR, grade and HER2 pathological characteristics were compared with metabolizer groups of the patients. No statistically significant change was observed across the groups $(\mathrm{p}=0.3, \mathrm{p}=0.4, \mathrm{p}=0=0.8$, $\mathrm{p}=0.5$ ).

To evaluate the development of metastasis by metabolizer groups a Log-Rank test, using the KaplanMeier method of analysis, was performed and no statistical significance was found $(\mathrm{p}=0.87$ ) (Figure 1).

\begin{tabular}{|lll|}
\hline \multicolumn{2}{|l|}{ Table 3. Incidence of metabolizer groups } \\
\hline & Frequency & $\%$ \\
\hline Ultra rapid metabolizer & 5 & 5.2 \\
Normal metabolizer & 74 & 77.1 \\
Intermediate & 11 & 11.5 \\
Poor & 2 & 2.1 \\
Total & 92 & 95.8 \\
\hline
\end{tabular}

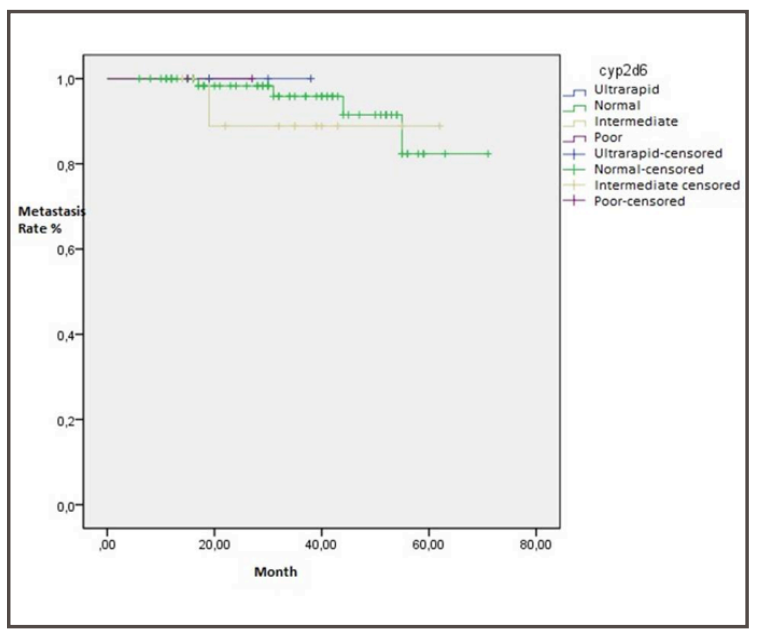

Figure 1. Kaplan-Meier survival curve for the evaluation of metastasis development by metabolizer groups

\section{DISCUSSION}

In patients with ER+ breast cancer, adjuvant tamoxifen therapy decreases the recurrence of breast cancer and the mortality rates of patients, leading to a substantial improvement in a 10 -year survival period. ${ }^{2}$ However, some studies have demonstrated that the response to tamoxifen was decreased due to impaired CYP2D6 genetic polymorphisms. ${ }^{4,5}$ Although some studies show that CYP2D6 genotype, which plays an important role in the metabolism of tamoxifen, has an effect on the recurrence of breast cancer, others have contradictory findings. ${ }^{6-9}$

Alleles and genotypes may vary by ethnicity. While CYP2D6*10 polymorphism is the most common polymorphism in Asians, $* 4$ allele, $* 1$ allele and $* 41$ allele were commonly seen in Caucasian, Brazilian and Indian populations, respectively. ${ }^{10-12}$ In our study $* 1$ allele, which is also known as the wild type, was the most common in the Turkish population. In the NM group the most common allele pair was CYP2D6*1*2 with a percentage of $77.1 \%$. 
Table 4. Distribution of metabolizer groups in some countries.

\begin{tabular}{|lllll|}
\hline Populations & PM (\%) & IM (\%) & NM (\%) & UM (\%) \\
\hline Spain $(n=91)$ & 11.1 & 49 & 34 & - \\
Korea $(n=716)$ & 6.7 & 69 & 24 & - \\
Brazil $(n=97)$ & 4.1 & 4.1 & 88.4 & 3.1 \\
Turkey $(n=92)$ & 2.1 & 11.5 & 77.1 & 5.2 \\
\hline
\end{tabular}

PM: Poor metabolizer, IM: Intermediate metabolizer, NM: Normal metabolizer, UM: Ultrarapid metabolizer

When the incidence of metabolizer groups were considered by population, Spanish and Korean populations most commonly had IM genetic polymorphisms with an incidence of $49 \%$, whereas the incidence of PM allele was highest in Caucasians (CYP2D6*4) and Europeans, with a rate of $20 \%$. It was $1-2 \%$ in Asians and 2-7\% in Africans. ${ }^{13}$ In the Brazilian population, the incidence of NM CYP2D6 polymorphisms was shown to be $88.4 \% .^{10,11,14}$ In our study, the incidence of NM CYP2D6 gene polymorphism was found to be $77.1 \%$ (Table 4).

In studies evaluating the correlation between pathological features of patients with breast cancer and CYP2D6, no significant difference was found across the NM, IM, UM and PM groups in terms of histological grade, ER, PR and HER2. ${ }^{10}$ When CYP2D6 metabolizer groups were evaluated for nodal metastasis, no statistically significant difference was observed and some studies demonstrated that nodal metastasis was statistically more common in the PM group compared to other metabolizer groups (IM, UM) ${ }^{1,10,15}$ In our study, no significant difference was found among the NM, IM and PM groups in terms of histological grade, ER, PR and HER2 status of the tumor.

When disease recurrence or metastasis is evaluated by metabolizer groups, despite the presence of the studies that show statistical significance with rates equal to $7.7 \%$ in the NM group, $7.9 \%$ in the IM group and $37.5 \%$ in the PM group ${ }^{10}$, there are other studies that show that CYP2D6 genotype had no important effect on disease recurrence. ${ }^{1,16}$ In our study $5.4 \%$ of the NM group and $9.1 \%$ of the IM group developed metastasis. No metastasis was observed in the PM and UM groups and no statistical significance was detected $(\mathrm{p}=0.87)$. This may be explained by the accumulation of the groups with gene duplication and inactive alleles in T1 and N0 group and by the short follow-up time. When 5-year and 10-year adjuvant tamoxifen use was compared based on the Atlas study, a better prognosis was demonstrated with 10-year tamoxifen use. Therefore, although it is a contradictory subject, many factors that change the efficacy of tamoxifen, especially the roles played in its metabolism, are still being considered. ${ }^{17}$

In conclusion, CYP2D6 genetic polymorphisms were investigated in studies conducted on various populations because they show differences in ethnic groups and in terms of therapeutic response. In this study, we investigated CYP2D6 genetic polymorphisms with the main role of observing the activity of tamoxifen in the Turkish population and we demonstrated the presence of the NM group in the majority of patients with non-metastatic breast cancer. Accordingly, although the correlation between metabolizer groups and the response to tamoxifen is contradictory, the majority of our patients will not have a surprising response to tamoxifen, especially in terms of efficacy, because they belong to the NM group. Following the study that demonstrated a better prognosis after 10 years of adjuvant tamoxifen use, it was suggested that tamoxifen could be used for a longer term, raising our need for information about the efficacy of tamoxifen. Furthermore, the need for longer follow-ups, due to the early stage of the disease, must be addressed in order to establish a correlation between recurrence of metastasis and survival by differing metabolizer groups.

\section{REFERENCES}

1. Morrow PK, Serna R, Broglio K, et al Effect of CYP2D6 polymorphisms on breast cancer recurrence. Cancer 118: 1221 1227, 2012.

2. Stearns $\mathrm{V}$, Johnson MD, Rae JM, et al. Active tamoxifen metabolite plasma concentrations after coadministration of tamoxifen and the selective serotonin reuptake inhibitor paroxetine. J Natl Cancer Inst 95:1758-1764, 2003

3. Desta Z, Ward BA, Soukhova NV, Flockhart DA. Comprehensive evaluation of tamoxifen sequential biotransformation by 
the human cytochrome P450 system in vitro: prominent roles for CYP3A and CYP2D6. J Pharmacol Exp Ther 310: 10621075, 2004

4. Kiyotani K, Mushiroda T, Sasa M, et al. Impact of CYP2D6*10 on recurrence-free survival in breast cancer patients receiving adjuvant tamoxifen therapy. Cancer Sci 99: 995-999, 2008.

5. Kiyotani K, Mushiroda T, Imamura CK, et al. Significant effect of polymorphisms in CYP2D6 and ABCC2 on clinical outcomes of adjuvant tamoxifen therapy for breast cancer patients. J Clin Oncol 28: 1287-1293, 2010.

6. Newman WG, Hadfield KD, Latif A, et al. Impaired tamoxifen metabolism reduces survival in familial breast cancer patients. Clin Cancer Res. 14: 5913-5918, 2008.

7. Okishiro M, Taguchi T, Kim SJ, et al. Genetic polymorphisms of CYP2D6*10 and CYP2C19*2,*3 are not associated with prognosis, endometrial thickness, or bone mineral density in Japanese breast cancer patients treated with adjuvant tamoxifen. Cancer 115: 952-961, 2009.

8. Kelly CM, Juurlink DN, Gomes T, et al. Selective serotonin reuptake inhibitors and breast cancer mortality in women receiving tamoxifen: a population based cohort study. BMJ 340: c693, 2010

9. Werner $\mathrm{S}$, Matthew PG, Ute $\mathrm{H}$, et al. Association Between CYP2D6 Polymorphisms and Outcomes Among Women With Early Stage Breast Cancer Treated With Tamoxifen JAMA 302: 1429-1436, 2009.

10. Park HS, Choi JY, Lee MJ, et al. Association between genetic polymorphisms of CYP2D6 and outcomes in breast cancer patients with tamoxifen treatment. J Korean Med Sci 26: 1007-1013, 2011

11. Antunes MV, Linden R, Santos TV, et al. Endoxifen levels and its association with CYP2D6 genotype and phenotype: evaluation of a southern Brazilian population under tamoxifen pharmacotherapy. Ther Drug Monit 34: 422-431, 2012.

12. Lim JS, Chen XA, Singh O, et al. Impact of CYP2D6, CYP3A5, CYP2C9 and CYP2C19 polymorphisms on tamoxifen pharmacokinetics in Asian breast cancer patients. Br J Clin Pharmacol 71: 737-750, 2011.
13. Bradford LD. CYP2D6 allele frequency in European Caucasians, Asians, Africans and their descendants. Pharmacogenomics 3: 229-243, 2002

14. Ramón y Cajal T, Altés A, Paré L, et al. Impact of CYP2D6 polymorphisms in tamoxifen adjuvant breast cancer treatment. Breast Cancer Res Treat 119: 33-38, 2010.

15. Li H, Feng $L, X u Y$, et al. The association of CYP2D6 ${ }^{*} 10$ polymorphism with breast cancer risk and clinico-pathologic characteristics in Chinese women. Acta Oncol 45: 597-601, 2006.

16. Lash TL, Cronin-Fenton D, Ahern TP, et al. CYP2D6 inhibition and breast cancer recurrence in a population-based study in Denmark. J Natl Cancer Inst 103: 489-500, 2011.

17. Davies C, Pan H, Godwin J, et al. Adjuvant Tamoxifen: Longer Against Shorter (ATLAS) Collaborative Group. Long-term effects of continuing adjuvant tamoxifen to 10 years versus stopping at 5 years after diagnosis of estrogen receptor-positive breast cancer: ATLAS, a randomised trial. Lancet 381: 805-816, 2013

\section{Correspondence}

Dr. Meral GÜNALDI

Dr. Sadi Konuk Araştırma ve Eğitim Hastanesi

Tıbbi Onkoloji Bölümü

Bakırköy

ISTANBUL / TURKEY

Tel: (+90.505) 2180300

e-mail: meralgunaldi@gmail.com 